TTR

Traduction, terminologie, re?daction

\title{
Translators on a Tight Rope: The Challenges of Translating Edwidge Danticat's Breath, Eyes, Memory and Patrick Chamoiseau's Texaco
}

\author{
Marie-José N’Zengou-Tayo et Elizabeth Wilson
}

Volume 13, numéro 2, 2e semestre 2000

Les Antilles en traduction

The Caribbean in Translation

URI : https://id.erudit.org/iderudit/037412ar

DOI : https://doi.org/10.7202/037412ar

Aller au sommaire du numéro

Éditeur(s)

Association canadienne de traductologie

ISSN

0835-8443 (imprimé)

1708-2188 (numérique)

Découvrir la revue

Citer cet article

N’Zengou-Tayo, M.-J. \& Wilson, E. (2000). Translators on a Tight Rope: The

Challenges of Translating Edwidge Danticat's Breath, Eyes, Memory and Patrick

Chamoiseau's Texaco. TTR, 13(2), 75-105. https://doi.org/10.7202/037412ar
Résumé de l'article

Traduire Breath, Eyes, Memory d'Edwidge Danticat et Texaco de Patrick Chamoiseau : un défi pour les traducteurs - Pour les intellectuels et les universitaires de la région des Antilles, la traduction des textes littéraires régionaux a un rôle capital à jouer pour permettre de dépasser les barrières linguistiques et contribuer à l'intégration régionale. Or, la plupart des maisons d'édition sont implantées dans les pays industrialisés du nord c'est-à-dire dans des pays ayant eu des intérêts coloniaux dans la région. De plus, le public cible de ces maisons d'édition vit dans une région qui a toujours eu tendance à rechercher l'exotisme des Antilles. Il s'ensuit que la traduction des oeuvres littéraires caribéennes peut se révéler un exercice périlleux puisque le traducteur devra sans cesse négocier entre la tentation de l'exotisme et le respect de la culture caribéenne. Par ailleurs, et du moins pour les pays anglophones, francophones et néerlandophones des Antilles, la question du bilinguisme se pose également : utilisation du français et du créole guadeloupéen / haïtien / martiniquais, de l'anglais et du créole jamaïquain / trinidadien ou encore des créoles à base française dans le cas de la Dominique, de la Grenade et de Sainte-Lucie. C'est donc dans ce contexte que nous avons analysé deux traductions, l'une allant de l'anglais vers le français (Breath, Eyes, Memory d'Edwidge Danticat, 1994) et l'autre du français vers l'anglais (Texaco de Patrick Chamoiseau, 1992). Nous avons étudié la manière dont les traductrices arrivaient à faire passer les cultures haïtienne et martiniquaise. Nous avons également discuté leur traitement des instances de bilinguisme, présentes dans les deux textes. Une traductrice y est mieux parvenue que l'autre, ce qui nous a conduites à soulever le problème de la traduction " universitaire » par rapport à la traduction " non-universitaire ». Nous en concluons que les universitaires caribéens se doivent de prêter une attention particulière aux traductions des oeuvres littéraires de la région puisque ces dernières, bien que ne visant pas en premier lieu le public régional, auront néanmoins un impact sur les relations interculturelles dans la région.

Tous droits réservés ( $\odot$ TTR: traduction, terminologie, rédaction - Les auteurs, Ce document est protégé par la loi sur le droit d’auteur. L’utilisation des 2000 services d'Érudit (y compris la reproduction) est assujettie à sa politique d'utilisation que vous pouvez consulter en ligne.

https://apropos.erudit.org/fr/usagers/politique-dutilisation/ 


\section{Translators on a Tight Rope: The Challenges of Translating Edwidge Danticat's Breath, Eyes, Memory and Patrick Chamoiseau's Texaco}

\section{Marie-José N'Zengou-Tayo et Elizabeth Wilson}

Translators and thus translations are mediators. Of course in their appropriation of something not theirs to begin with they risk damaging or misrepresenting what they have appropriated, even when they are benevolent or unthinking. Mediators may be inherently incapable of complete neutrality. And yet whether presumptuous or subservient, they are indispensable links. [...] they not only cross boundaries, they also simultaneously set them and break them.

Marilyn Gaddis Rose, Translation as Literary Criticism, Translation as Analysis (1997, p. 12)

From a Caribbean perspective, translation of Caribbean literary works into the other languages of the region is viewed as part of the integration effort both political and cultural. Translation falls in line with current ideology spreading in the region thanks to writers like Kamau Brathwaite (submarine unity), Édouard Glissant (crosscultural poetics) and Antonio Benitez-Rojo ('supersyncretic' nature of the cultures in the Caribbean). However, a look at the market for literary translation shows that the targeted readership is not from the Caribbean but from northern countries (the rich industrialized North). The economic conditions of translation seem to duplicate in some ways the past 'colonial' relationship of writers striving to 
obtain recognition from the metropolis. Yet the situation has become more complex because of the emergence of a countercolonial discourse and a more critical approach to translation. For instance, commenting on the English translations of Maryse Condé's novels, Doris Kadish and Françoise Massardier-Kenney (1996) show some of the pitfalls inherent in the translation of Caribbean works. One is the translation of the language register. Commenting on the English version of La vie scélérate, Tree of Life, by American writer Victoria Reiter, Massardier-Kenney highlighted the translator's consistent use of African-American dialect in the dialogues, while in Condé's texts, the characters were middle-class Blacks using various levels of French (p. 255). This choice led to a distortion of the original. Consequently, all the author's efforts to convey the dignity and the strength of the oppressed African-American characters were minimized in the translation. Massardier-Kenney judged that it also revealed the ideological bent of the translator (p. 259), meaning her assumption of a single register of 'African-American dialect' as the standard speech among African-Americans independent of their social class. Translator Bridget Jones (1987) effected a similar transposition in her translation of the Haitian novel Cathédrale du mois d'aout (Cathedral of the August Heat). While the author Pierre Clitandre wrote most dialogues in hexagonal French slang, Jones successfully conveyed this register through Jamaican Creole in her translation. The result was much more convincing, though her choice of Jamaican English (and not Trinidadian English for, example) was criticized ${ }^{1}$, which raises also the issue of which dialectal form of Caribbean English/French/Spanish to choose when translating Caribbean texts.

Both Kadish and Massardier-Kenney (1996) also discussed how the translator's gender influences his/her translation. In her comments on the translation of Maryse Condé's Moi, Tituba sorcière... noire de Salem by Richard Philcox, Kadish showed that the translator tended to overlook references to specific female conditions in the text (pregnancy, maternity). He either used understatements or omitted some specific allusions (pp. 239-240).

\footnotetext{
${ }^{1}$ Discussions at a seminar of the Institute of Caribbean Studies, U.W.I., Mona, 1989.
} 
In her conclusion, Massardier-Kenney draws attention to the fact that:

[...] l'identité culturelle, politique, sociale et sexuelle du traducteur ou de la traductrice a une importance cruciale sur la traduction obtenue et que toute traduction reflète l'idéologie du traducteur tout aussi bien que celle de l'auteur. (p. 257)

In the case of the Caribbean, ideology is an extremely sensitive issue because of the colonial past. Translations of literary texts run the risk of reviving colonial stereotypes concerning the region. As mentioned by Richard Philcox (1996) in his article "Traduire Traversée de la mangrove,"

La Caraïbe bénéficie d'une certaine fascination chez le lecteur occidental, et donc est admise comme sujet de roman. (p. 228)

Thus he notes that whatever she does or says, Maryse Condé cannot avoid the stereotype however attractive it may be. What is true for Maryse Conde is also true for any other writer from the region. The translator of Caribbean texts, therefore, faces an ethical dilemma, which is how to avoid cultural stereotyping of the text and exoticism. As Jean-Louis Cordonnier (1995) reminds us:

Le fait qu'il y ait une hiérarchisation et une inégalité entre les cultures n'est pas de peu d'importance pour la traduction. [...] Politique et culture sont indissociablement liées. Ces cultures en train de naître ont rencontré d'autres peuples, d'autres nations. La découverte du Nouveau Monde révèle le même rejet, l'impossibilité de constituer le Même avec l'Autre extérieur.

(p. 11)

Cordonnier advocates the need for ethics in translation because translation modes bear the marks from their cultures and show how the Same confronts the Other (p. 13). For Cordonnier, contemporary translators should contribute to the effort to establish relationships with the Other, revealing the Other, yet without concealing the Same (p. 15). The translator should help in transforming human relationships, revealing the individual-to-come as a 'de-centered' human being (p. 15). Literary translation is a way of appropriating a foreign culture in order to develop one's personality. It plays an important part in the development of world 
literature (Berman, 1984, pp. 89-90). It also raises the problem of ethnocentrism (Berman, 1984, Cordonnier 1995). Cordonnier reminds us that the European tradition of translation developed on the Roman model of cultural appropriation-assimilation and (political) annexation (Roman imperialism) leading to ethnocentrism (pp. 15-16). The encounter with a 'New World' in the Western Hemisphere both shook and reinforced this tradition. The conquest of the Americas revealed among other things that the 'Western ego' was not ready to accept the Other as a different cultural being (p. 16). Cordonnier argues that at the core of the translation process is the negotiation of the issue of 'otherness.' He identifies assimilation-appropriation and respect of difference as two poles between which the translator is oscillating (p. 18).

Cordonnier's and Berman's discussions of translation are of particular interest for us in the Caribbean because of the temptation of exoticism present in Northern responses to our cultures. The epistemological debate raised, on the one hand by Cordonnier about the translation of Latin-American literature, and on the other hand, by Berman about the impact of translation in German culture, will inform our approach to two recent translations of Caribbean works. One is the English translation of Patrick Chamoiseau's acclaimed novel, Texaco, the other is Le cri de l'oiseau rouge, the French translation of Edwidge Danticat's Breath, Eyes, Memory. In the case of Danticat, reference will also be made to the translation of her short story collection Krik? Krak! Chamoiseau's novel was translated by Haitian-American RoseMyriam Rejouis with the collaboration of Val Vinokurov (1997) while Danticat's book was translated by Metropolitan French Nicole Tisserand. Réjouis's translation was done within the framework of her scholarly research while Tisserand is a professional translator contracted by French publisher Pygmalion/Gérard Watelet. We should note the 'invisibility' of Danticat's translator contrasting with the 'high profile' of Chamoiseau's. At the end of the English translation of Texaco there is an 'Afterword' in which Réjouis discusses her translating choices (pp. 393-396). We make these distinctions since they will be part of our discussion of the two translations. Our paper will focus on selected aspects of these translations. We are interested in the choices made by the translators in order to convey the Caribbean environment and culture. The issue of language is also 
another element to be discussed because of the multilingual situations in these texts (French Martinican Creole, Martinican French and Hexagonal French in Chamoiseau; American English, Haitian Creole, English translation of French and Haitian Creole in Danticat).

We have identified the following questions facing the translators: should they use regional expressions (Caribbean French and English) or should they use the 'metropolitan' forms (Hexagonal French/American or British English)? How should they convey the writers' idiosyncrasies in the target language? For instance, should the translator 'flatten' Chamoiseau's style or should he/she try to recreate the stylistic effects in English? In the case of Danticat, an additional challenge faced her translator, that is the presence of segments already translated from French and Creole in the English text. How could the translator identify them and 're-translate' them back into their original form?

We also asked ourselves to what extent inside knowledge of the Caribbean milieu would have an impact on the translations. Should we say that a good translation of a Caribbean text requires an in-depth knowledge of the region's cultures, the kind of knowledge acquired through personal experience or meticulous research? These questions are part of an on-going debate among scholars from the region and reflect our concerns about stereotyping and 'exoticizing' our culture. We do not pretend to have the answers to all these questions but we would like to make our contribution to the debate and help to take it one step further.

\section{Translating Breath, Eyes, Memory into French.}

The French title of Breath, Eyes, Memory, Le cri de l'oiseau rouge, initiates a relationship between text and reader quite different from the English original. While the English title hints at life and the importance of remembering, the French title draws attention to the symbol of the Caco family, the Cardinal bird, whose hue becomes bright red when it is dying. This choice implies the reading of a 'family Saga' and might be held partly responsible for the negative reactions of some Haitian circles in Haiti. The comments on the back cover may also have contributed to the misunderstanding of the French-speaking Haitian readership with the presentation of 
Danticat as a promising talent in 'American literature' (back cover of the pocket edition, 1995) ${ }^{2}$. At any rate, it is clear that the Haitian and the French Antillean readership were too small to be the targeted audience of the French translation. Therefore, we must acknowledge the fact that we are criticizing from a Caribbean viewpoint a product which was not primarily directed at us. As a Haitian and a Jamaican reading the French translation of Danticat, we are struck when we measure the divorce between the original and the translation in conveying Haitian culture.

In reading the French version, we first noticed the unevenness in the tone, which was mainly due to the translator's shift between historic past and passé composé $e^{3}$. This creates a problem since the translator's hesitation between the two French past tenses altered what Richard Philcox calls the tone and the music of the text (Op. Cit., pp. 222-226). The English past tense creates a continuity of tone that is in line with the 'memoirs' genre implied in the English title ('Memory'). In the French version, the translator had to negotiate every now and then between three French past tenses. While the imperfect did not create any problem, the tense shift between past historic and 'passé composé' did not occur smoothly. It gave an impression of clumsiness in style whenever the past historic and the 'passé composé' were used concurrently. For instance, the very first chapter of the novel starts with the present perfect (pp. 13-14). It reminds the reader of the beginning of Camus's $L$ 'étranger and implicitly leads him/her to expect this type of narrative tone in the translated version. At the bottom of page 14, however, the narration shifts after a dialogue to the conventional historic past until page 19 where it reverts to the 'passé composé.' It shifts back to the historic past on page 24 until the end of the chapter. The same thing happens repeatedly all

\footnotetext{
${ }^{2}$ We are referring here to the hot debate that took place at the Institut Français d'Haïti in November 1998 during a panel on new trends in Haitian literature, during which Danticat's place in Haitian literature was denied by some participants. We also refer to comments made by some French-speaking readers who felt that she was using Haitian material in order to achieve recognition in the US at the expense of Haitian culture.
}

${ }^{3}$ Because of the difference in their syntactic values (aspects), we kept the French for 'passé composé' to avoid confusion with the English 'present perfect.' 
through the novel and is particularly disturbing in the scenes of great tension. For example, in chapter 17, when Sophie Caco witnesses the brutality of the Tontons-Macoutes (the Duvalierist militia) against a charcoal vendor (p. 146), the narration of the scene starts in past historic/imperfect and then shifts to the 'passé composé/imperfect.' While the imperfect fits well in its normal use to indicate background actions, it is hard to accept the constant switch from past historic to 'passé composé.' At first, one has the impression that the 'passé composé' would be used whenever the narrator is implicated in the action, yet this is not always the case.

\section{English:}

Louise rushed back to her stand. My grandmother and I hurried to the flamboyant and started on the road home.

I turned back for one last look. The coal vendor was curled in a fetal position on the ground. He was spitting blood. The other Macoutes joined in, pounding their boots on the coal seller's head. Every one watched in shocked silence but no one said anything.

My grandmother came back for me. She grabbed my hand so hard my finger hurt. (p. 114)

French:

Louise se précipita vers son stand. Ma grand-mère et moi avions hâte d'atteindre le flamboyant et de prendre le chemin de la maison.

Je me suis arrêtée pour jeter un dernier coup d'oeil derrière moi. Le marchand de charbon de bois était couché par terre, replié sur lui-même. Il crachait le sang. Les autres Macoutes, qui s'étaient mis de la partie, lui écrasaient la tête à coups de bottes. Tous regardaient dans un silence horrifié. Personne n'a rien dit.

Ma grand-mère revint vers moi. Elle m'attrapa la main avec une telle violence que j'en eus mal aux doigts.

(p. 146, emphasis added)

Incidentally, we must comment on the translation of 'hurried to the flamboyant' by 'avions hâte d'atteindre le flamboyant' (use of imperfect instead of historic past and the modality introduced by the translation of 'hurried' by 'avoir hâte' instead of 'se dépêcher / se hâter'). The change in the translation introduces a distortion compared with the original. 'Se dépêcher /se hâter' would have allowed the translator to continue with the historic past and 
contributed to smooth the reading of the passage. The two occurrences of the 'passé composé' open and close the ensuing paragraph and give an impression of immediacy. The narrator is implicated in the first use of the 'passé composé' while the other witnesses are in the second one at the end of the paragraph. The event itself is described with the imperfect and enclosed between the two 'passé composé.' It gives the impression of the translator's desire to highlight the brutality of the scene and contrast the passivity of the spectators including the narrator herself. This interpretation is strengthened by the fact that the final sentence of the original was broken into two short sentences in a paratactic construction. Yet, in the following paragraph the shift back to the historic past destroys the effect. The same contradictory effect is created in one of the most dramatic sequences of the novel, the 'test' episode in which Martine verifies if her daughter Sophie, the main protagonist and narrator, is still a virgin (pp. 107-109). There again, the use of the 'passé compose' alternates with that of the past historic. The section in the chapter starts in the past historic. The narration of the test sequence itself intersperses both 'passé composé' and past historic. The use of 'passé composé' coincides with the description of the narrator's inner turmoil and the test itself. As Émile Benveniste (1966) reminds us: "Le parfait [passé composé] à la première personne [est la] forme autobiographique par excellence. Le parfait établit un lien vivant entre l'événement passé et le présent où son évocation trouve place. C'est le temps qui relate les faits en témoin, en participant; [...]." (p. 244). One would therefore understand the use of 'passé composé' in these highly emotional scenes in which past painful experiences are remembered. The past historic follows to introduce the story told by Martine while she tests her daughter and then, to recount her action after the test. The 'passé composé' reappears immediately after to convey the despair of the narrator. Ironically, we found a case in which the use of 'passé composé' would be justified, yet the translator rendered the English past tense by a French pluperfect:

English:

It took me twelve years to piece together my mother's entire story. By then it was already too late. (p. 61)

French:

Il m'avait fallu douze ans pour mettre bout à bout les morceaux de l'histoire de ma mère. Mais à ce moment-là c'était déjà trop 
tard. (p. 82)

The main problem lies in the past historic, which is associated with the account of historical events. We have to turn to French critic Roland Barthes in order to find an explanation for the discomfort we intuitively felt when the translator shifted to the past historic. In his essay, Le degré zéro de l'écriture (1953), Barthes comments on the past historic and the novel in the following terms:

[...] soutenant une équivoque entre temporalité et causalité, il [le passé simple] appelle un déroulement, c'est-à-dire une intelligence du Récit. [...] Il suppose un monde construit, élaboré, détaché, réduit à des lignes significatives, et non un monde jeté, étalé, offert. [...]

Le passé simple est donc finalement l'expression d'un ordre [...]. (p. 26, emphasis added)

In Breath, Eyes, Memory, the narrator Sophie Caco tries to piece together various family stories in order to be able to understand not only her mother's but also her own life. This could justify the choice of the past historic by the translator in order to convey this attempt at recreating an order. Yet, she misses the fact that Sophie presents her fragmented world as such and acknowledges herself the fact that it was too late when she managed to make some sense out of her mother's experience (Breath, Eyes, Memory, p. 61/Tr., p. 82).

It is difficult to say which of the systematic uses of 'passé composé/imperfect' or 'past historic/imperfect' would have been more effective. We are perfectly aware of the dilemma facing the translator. It is clear that her hesitation was due to the first person narrative voice of the novel, which alternates between narrative and autobiography. As an 'autobiography' Breath, Eyes, Memory belongs to the discourse type of enunciation as defined by French linguist Émile Benveniste (1966). We have the feeling that a more consistent use of the 'passé composé/imperfect' would have been more effective because of the guarded tone of the original. As it is, the random shifting from one to the other distorts and destroys the effect of Danticat's style and does not do justice to the pervasive melancholy contained in the original.

Another linguistic element drew our attention in the 
French translation of Danticat. It is the fact that her mother tongue is not English though she published her fictional work in this language. It was interesting for us to examine how the translator managed to 'translate back' the turns of phrase in English that were obviously translations from French and Creole. In her 1996 interview with Renée Shea in Callaloo (vol. 19, $\mathrm{n}^{\circ}$ 2), Danticat commented on her relationship with languages (English, French and Haitian Creole). She elaborated on English as her 'stepmother tongue' in the following terms:

I don't mean it derogatively though; [...] I thought of a stepmother in the sense that you have a mother tongue and then an adopted language that you take on because your family circumstances have changed, sometimes not by your own choice. [...] l've always thought my relationship to language is precarious because in the first part of my life, I was balancing languages. As I was growing up, we spoke Creole at home, but when you go out, you speak French in the office, at the bank. If you didn't speak French at my school, the teacher would act like she didn't hear what you were saying [...] So I've always felt this dichotomy in language anyway. (pp. 387-388)

It was important for us to examine the French translation from this viewpoint. 'Writing in translation' led Danticat to develop, consciously or not, a literary style that is reminiscent of the aesthetics of the writers of the Créolité Movement (Éloge de la créolité, pp. 23-24; pp. 33-50), meaning use of Creole and French in the English text, transposition of French and Creole syntax into English. It is not by chance that the translation of her book was nominated for the 1995 Prix Carbet ${ }^{4}$. Therefore, it was interesting to look at whether the translator managed to recover the underlying French and Creole from the text.

Creolizing the English language marks the Caribbeanness of the text, and as such, adds an exotic flavor to it. For instance, in chapter 13 , the tap-tap driver declares his love in a language that

\footnotetext{
${ }^{4}$ The Prix Carbet is a coveted literary award given annually to a FrenchSpeaking Caribbean writer in Martinique. Danticat was awarded the Prix Carbet in 1999 for her second novel The Farming of the Bones (1998) translated as La récolte douce des larmes. (Paris, Grasset 1999)
} 
reminds us of Emile Roumer's poem "Marabout de mon coeur". The realistic imagery accompanying the declaration of love is inspired by that poem.

\section{English:}

"I would crawl inside your dress and live there. I can feed on your beauty like a leech feeds on blood. I would live and die for you. More than the sky loves its stars. More than the night loves its moon. More than the sea loves its mermaids. Strike me, thunder, it's no lie. We do not know one another, I know. Still I must tell you. You can be the core of my existence. The ' $I$ ' of my 'We.' The first and last letter of my name, which is 'Yours,' your humble servant and transporter." (p. 93)

\section{French:}

Je voudrais ramper sous ta robe et y passer ma vie. Ta beauté me nourrirait comme le sang nourrit la sangsue. Je pourrais vivre et mourir pour toi. Comme le ciel aime les étoiles. Comme la nuit aime la lune. Comme la mer aime les sirènes. Que la foudre me frappe si je mens! On ne se connaît pas, je le sais. Mais ça ne m'empêchera pas de te le dire. Tu deviendras le centre de mon existence. Le "Je" de mon "Nous". La première et la dernière lettre de mon nom, qui est "Tout à toi", ton humble serviteur et chauffeur. (p. 117)

We could criticize the transfer of the subject into object (I can feed [...] / Ta beauté me nourrirait) as well as the change in the comparison from the degree of superiority (more than) to equality (comme) because the Creole turn of phrase gets lost in French. Similarly, the italicized "Strike me, thunder[...]" (p. 93) is translated from the Creole "Tonè krazé $\mathrm{m}$ si m manti." It would have been better to translate "Que le tonnerre m'écrase..." taking into account that "que la foudre me frappe..." is a literary language register that is out of tune with the rest of the passage. It is to be noted that in some cases the translator chooses colloquial French (omission of 'ne' in the negative form, disjointed construction of sentences "les dunes et les bosses de la route, c'est pas moi qui les ai faites" [p. 94]). In other cases, she uses standard French or a formal level of language.

\footnotetext{
${ }^{5}$ Haitian poet Émile Roumer (1903-1987) was a member of the Indigenist Movement, which promoted Haitian Creole as a literary language.
} 
In cases where the paratactic construction of the English reproduces the Creole juxtaposition of successive actions or processes, the use of the logical connectors suppresses the Creole shadow behind the English as seen in the following example:

English:

People who have been away from Haiti fewer years than you, they return and they pretend they speak no Creole. (p. 95, emphasis added)

\section{French:}

Il y a des gens qui sont partis de Haiti moins longtemps que toi; quand ils reviennent, ils font comme s'ils ne savaient plus un mot de créole. (p. 119, emphasis added)

The Creole structure "yo tounen / epi yo di / yo pa pale kreyòl," transfers well into English. It is lost in the French version because of the latter's stylistic preference for general / abstract words and logical connections ('quand' and 'comme si').

The suppression of 'ne,' which is common in spoken and colloquial French, becomes problematic when original dialogues are written in Standard English. In these cases, the translator misses the political linguistic point made by Danticat. Particularly, when she mentions that her characters are speaking Haitian Creole and reports the direct speech in Standard English, it is clear that she wants to avoid the connotation of low-status associated with Creole. By using colloquial French in some dialogues, the translator obtains just the opposite effect, reminding the reader of the lower class of the protagonists (p. 73). The result is not as disturbing as in the case of Tree of Life (Cf. supra, MassardierKenney's discussion of Reiter's translation) though annoying because it seems to occur at random. Sometimes on the same page, the dialogue switches from colloquial to formal use of negation (pp. $32-33 ; 49-50 ; 72-73 ; 131-133$ ) as illustrated below, while the English text (pp. 19-20) used the standard form (does not, did not) instead of the spoken abbreviations (doesn't, didn't):

À présent, Sophie, ta mère veut te voir. Elle veut pas que tu oublies qui est ta véritable maman. Quand elle t'a confiée à moi on savait, elle et moi, que c'était provisoire. Tu n'étais qu'un bébé à l'époque. Elle t'a laissée ici parce qu'elle partait dans 
une ville inconnue. Elle ne voulait pas prendre de risques avec toi. (p. 33, emphasis added)

As Caribbean readers living in the region, we examined closely the translation of elements referring to the region and its culture. On many occasions, the French translator overlooked these cultural features. We felt that had she been closer to the region or done more background research on Haitian literature, she would have made different choices. We have selected the most obvious instances for our discussion here.

In the novel, Sophie's aunt Atie addresses her mother as 'Old woman,' which sounds aggressive if one remembers the respect due to elders in Haitian society. However, 'Old woman'is the translation of 'granmoun' (older person or elder) which does not have a harsh connotation in Creole. Though Atie's relation with her mother is difficult, the French translation 'vieille femme' makes it more strident. Before resentment arose between the women, Atie called her mother 'old woman' (p. 23). It is a case where we felt that the underlying Creole expression 'granmoun' or better yet 'grann' could be substituted for the French. It does not have the harshness of the French but would still have a doubleedged meaning.

In some cases, translation errors revealed insufficient knowledge of Haitian culture and languages (both French and Creole). For instance, the Haitian currency, the 'gourde' was until quite recently a paper currency, which explains why the driver "straightened out the dirty gourdes and counted them quickly" (p. 95). In the translation the bank notes are transformed into coins and the driver stretches his hand to receive them (p. 120). Someone familiar with Haitian reality would know that women (especially market women) fold their bank notes to keep them in a bag in their bras (in the text itself, p. 6; in translation, p. 16). In another instance, Atie, the narrator's aunt, refers to her and her sisters as 'daughters of the hills' (p. 20). In translating 'hills' by its hexagonal French equivalent 'collines,' instead of the Caribbean French 'mornes,' the translator missed the cultural connotation conveyed by the word in Haiti (filles des mornes), meaning 'uneducated, cut off from civilization and progress, marginalized.' 
Naming is very important in Haitian culture and particularly in peasant and working class culture. Usually the name given to a child alludes to the circumstances surrounding his or her birth. Names are meaningful and Haitian writers have used this peculiarity in their fiction contributing to some extent to exoticizing Haitian peasants' and workers' names. The children's names listed on page 6 belong to this tradition and some are 'pwent' names ${ }^{6}$. The translation for some of them is not very successful. For instance, 'First-born' is translated 'Premier-ne' and 'Enough-boys' by 'Assez-de-gars.' It would have been more accurate to translate the first one in Haitian French 'Monpremier,' and the second in Haitian Creole 'Aselhòm' or in its French spelling of 'Acélhomme' found in many Haitian novels. The translation of 'God-Given' should have been 'Dieudonne' and not 'Don-de-Dieu' (p. 17). Similarly problematic was the translation of 'No Misery'. The translator's choice of 'Pas de Misère' rings false to a Haitian reader who recognizes 'nanpoint mizè' (something that was not apparent in the English). These are details but they contributed to suspicions raised about Danticat's intentions in some Haitian circles and somewhat validated the accusation of exoticizing Haitian culture in order to seduce an American audience.

Though errors in Tisserand's translation could be dismissed as minor and unimportant for the mass-market readership, some of them are debatable from the viewpoint of accuracy and consistency. For instance, 'Cassava breads' (p. 10) is translated 'pain de manioc' (p. 22) and 'Cassava sandwiches' (p. 114 ) is rendered by 'galettes de cassave' (141). The second translation is culturally more accurate than the first one. In Haiti, 'cassava bread' has the form of large wafers cut into pieces to make sandwiches. In fact, 'galettes de cassave' or simply 'cassave' would have been a good choice for 'cassava breads.' 'Pain de manioc' was inadequate because in Haiti, 'manioc' is used for the plant itself, its leaves and roots as well as the flour obtained from the roots. The wafer (or bread) made from 'manioc' is called 'cassave.' Yet the main problem lies in the fact that the translator

\footnotetext{
6 'Pwent' names are names which allude to an event occurring or a comment made at the time of the birth. They are like coded messages understood by members of the family or close neighbors.
} 
did not go back to the first occurrence in order to make her translation consistent. The same thing occurs with the translation of 'pot-luck dinner.' It was first wrongly and awkwardly translated as 'dîner de fortune pris en commun' (p. 20) and then by 'dîners pris en commun à la fortune du pot' (pp. 23-24), which is more accurate, yet the first appearance of the expression was not corrected. When Atie visits her mother with Sophie, she greets her mother by saying "Old woman, I brought your child" (p. 23). In the French translation, it becomes "Vieille femme, je t'ai emmené ton enfant" (p. 37) instead of 'amener' and repeated page 130. Some errors are due to negligence more than mistranslation as such. For instance, 'les vieilles tantes,' though following closely the English original ("Old tantes - aunties -," p. 11), sounds clumsy in the French text, "les vieilles tantes - les tantines - et les grand-mères berçaient sur leurs genoux des bébés[...]," p. 23) instead of 'les grand-tantes.' or 'les tantes très âgées.' On this matter, we think that the publisher shares the responsibility (in the pocket edition at least): a careful proofreading would have prevented these blunders, the worst one being the mix-up which occurred at the end of chapter one and chapter two (pocket edition). The final page of chapter one was printed at the end of chapter two and vice-versa (pp. 30-35).

As far as 'popular wisdom' is concerned, the translator did not fare too badly. The fact that Danticat herself re-wrote some Haitian proverbs and popular sayings makes it hard to discuss the translator's choices. For example, the proverb 'joumou pa donnen kalbas' (literally, pumpkins do not produce calabashes, meaning 'like father/mother, like son/daughter') has been transformed into 'crabs do not make papayas;' hence the translation "les crabes ne font pas de papayes" (p. 45). However, from a broader viewpoint, it raises the issue of knowledge of the culture and translation. Would it be considered as 'over-translating' if knowing the original proverb had lead the translator to go back to it in the French version? We think that this was a good case where a translator's note reminding readers of the original would have been relevant, as Réjouis and Vinkurov did for Texaco (See infra).

We criticized how Tisserand dealt with the issue of tenses because it altered the "music and the tone" (Philcox, 1996) of Danticat's novel. Similarly, the cultural errors could not be 
overlooked because of the existence of an important body of Haitian literature in French. We felt that because of Tisserand's lack of background research, an opportunity for bridging the gap between the Haitian Diaspora in the United States and Haitians at home was missed. Yet, all these shortcomings in Tisserand's translation did not prevent the novel from reaching a large audience as evidenced by its publication in the pocket collection. Danticat herself endorsed it in her interview with Renée Shea (1996):

[...] it is a wonderful translation. I can't read Breath, Eyes, Memory anymore; [...] But when the French one came, I read it and really liked it. I liked it better! (p. 387)

This statement could be a reproach to us, critics (Maryse Condé accepted Tree of Life until she heard Kadish's comments) ${ }^{7}$. Yet, Danticat's enthusiasm confirms in a way Cordonnier's argument in Traduction et Culture (1995, pp. 14-15, p. 27), it is an interesting example of the 'strangeness' created by translation: Danticat's novel had become 'new' to her, it became 'something different,' an 'Other.'

\section{Texaco and its English Translation}

Certainly one of the most distinctive features of Patrick Chamoiseau's Texaco is his innovative, impressive manipulation of language. Chamoiseau's novel is particularly exciting in this respect. Judging from the enthusiastic reception of the English text, the translators have successfully conveyed Chamoiseau's tour de force. The press notices quoted at the beginning of the English version of Texaco speak to the exuberance, the sheer exhilaration of Chamoiseau's prose. "Soars and tumbles in effortless acrobatics at times ribald, poetic, lyrical and lewd, it dances across the page..." (Seattle Times). Or again: "The language of Texaco is absolutely, magically enchanting." (Los Angeles Times Book Review). Added to the success of Chamoiseau as a master stylist and storyteller, is the fact that as a fluent speaker of both Creole and French, one of the major effects of the novel is the way in which he plays with/on both languages. The text is replete with

${ }^{7}$ At the Pointe-à-Pitre Colloquium on Condé's Work, $14^{\text {th }}-18^{\text {th }}$ March 1995. 
puns, word-play, a variety of linguistic registers, code-switching, blurring the distinctions and complicating the relationship between French and Martinican Creole, creating what Milan Kundera in an earlier review of Chamoiseau's work called 'Chamoisified French' (Kundera, 1991) - a potential nightmare for the translator. Texaco, published by Gallimard (1992), won the prestigious Prix Goncourt. Texaco is a post-modern text which (self)-consciously deals with language and the process of writing:

Habiter le français de manière créole, tel fut l'un des principaux mots d'ordre de Patrick Chamoiseau, et des auteurs de la Créolité, cela tout autant qu'écrire en créole. (Karibel Magazine $\mathrm{n}^{\circ}$ 3, Nov.-Dec. 92, Karaib Perspectives, Martinique, p. 1)

As a créoliste, Chamoiseau is faithful to the aims set out in their manifesto. They promised that:

Notre plongée dans la créolité ne sera pas incommunicable mais elle ne sera non plus pas totalement communicable. Elle le sera avec ses opacités, l'opacité que nous restituons aux processus de la communication entre les hommes. (Éloge de la créolité, p. 53)

One of the reasons why the English translation of Texaco (1998, "Translated from the French and Creole by Rose-Myriam Réjouis and Val Vinkurov") is successful, despite the many potential pitfalls and some occasional lapses, may well have to do with the fact that in addition to her gifts as a translator and her insider's knowledge of the languages, region and culture, the translation has been executed in the context of a department of literary and translation studies by a translator who is also a literature scholar. This has an impact on the quality of her translation, since as Marilyn Gaddis Rose in her excellent work on translation and literary criticism reminds us:

Literary translation is a transfer of distinctive features of a literary work into a language other than that of the work's first composition. But literary translation is also a form of literary criticism. (p. 13)

Réjouis is a "Franco-Haitian living in the United States for the past eight years" (her own words) who together with her husband, "an American who speaks almost no French", set herself the task of rewriting the novel "into an English at once supple and 
communicative of the spirit of Chamoiseau's complex literary project." (Translators' "Afterword" to the English translation, Texaco, p. 396). At the center of Texaco is the primacy of the story-teller (le Marqueur de paroles) and his tale. 'The word' ('la Parole) is paramount. The world of Texaco/Texaco is a complex amalgam of diverse influences, strands, and histories: African, European, and Asian, which have gone to make up the creole world of the novel and of Martinican reality. Réjouis's "Afterword" recognizes the multifacetedness of both the text and the sociocultural context. The Caribbean is the site of what has been described by Benitez Rojo as a 'supersyncretic culture' or in Glissant's terms 'cultures composites.' The translation is sensitive to Chamoiseau's preoccupations as a créoliste and to the demands of the multi-voiced 'collage' with 'foreign smatterings' yet 'grounded in French,' which forms the text. ("Afterword," p. 395) The translators state that their text tries "to remain faithful to Chamoiseau's, to the rapport between Martinican creole and French in a Creole text with a French matrix." ("Afterword," p. 395). The result is a text, grounded in English, which manages to suggest like the original, this rapport with an essentially Creole community. In addition, the English translation often achieves a rendering of what Gaddis Rose calls 'the interliminal.' Gaddis Rose characterizes interliminality as "the gift translation gives to readers of literature." (Gaddis Rose, p. 7). She describes the interliminal (the threshold, the 'between') as what lies "between the source language and the target language" which is "unwritten but paraphrasable." In Chamoiseau's novel, by the very nature of the text, the 'interliminal' becomes significant. One cannot help making a link to the créoliste notion of 'opacité' expressed in Éloge de la créolité.

Unlike Breath, Eyes, Memory, the title of Texaco is not a source of difficulty or contention for translator or reader: the anglophone reader encounters the text, Texaco/Texaco, in exactly the same way as her/his French-speaking counterpart. Only readers familiar with Martinique would relate to its full significance from the outset, since they would know that it is a slum in Fort-deFrance, which sprung up near a derelict petroleum storage facility belonging to Texaco. However even from the first page, with the epigraphs, the translator/reader is faced with a challenge: "La ville était le sanctuaire de la parole, du geste, du combat." The 
translators' phrase 'of the gesture and the geste' necessitates the first instance in the text of an entry in the glossary because of the polysemy of 'geste.' Moreover: "You, game, are nothing but a cityblackman: that's where you have to speak from!" a quotation from Édouard Glissant, because of the ambiguity of the English word, 'game,' gives the reader no clue that it refers here to 'gibier': "Gibier[...] tu n'es qu'un nèg-bouk: c'est de là qu'il faut parler![...]" This epigraph permits the French reader an insight into the imaginative world, the trajectory of the text to be encountered, which is denied to the English-speaking reader. This is perhaps a limitation of the (necessarily) bilingual translator who reads/understands/apprehends a text and her/his translated version in/with both languages at the same time and another potential advantage in having a co-translator fluent in only one of the languages.

The translators' achievement is in communicating to the English-speaking reader the excitement, the richness, the rhythms, the effects, and what Richard Philcox describes as the 'musicality' of the text, in ways which evoke its diversity, variety and abundance.

The translators recreate in English the stylistic effects of such culture-specific passages as the following:

\section{French:}

Comment ne pas croire qu'il avait vu en cette occasion un nègre flamboyant, épais comme un fromager, nanti d'une barbe brumeuse, et pourquoi pas, de quelque mulet à z'ailes? S'il prit plaisir à me laisser ces illusions, mon Esternome me rappela tout de mêtme que juger le mancenillier à l'aspect de ses fruits, c'était mourir empoisonné, et que par ailleurs donc s'il vous plaît, procéder de même pour la figure boueuse de l'igname bocodji, c'était ignorer l'heureux de ce manger. (Texaco, p. 62)

\section{English:}

How could I disbelieve that he had seen a dazzling blackman then, thick like a silk-cotton tree, wearing a hazy beard, and why not, on some winged mule? If he took some pleasure in leaving me with such illusions, my Esternome reminded me all the same that to judge a manchineel by its fruits is to die from poison, and that by the same token, to look down upon the juice yam's 
muddy face is to miss the pleasure of that meal. (Texaco/Tr., p. 51)

By and large the translators' text retains the 'shape' of the original as well as its structures and appropriate lexicon, although one would have suggested keeping 'flamboyant' in view of the other references to trees. Here is a passage from Chamoiseau's description of Texaco from the section "Temps Béton", ("The Age of Concrete"):

SOL LIBRE. À Texaco, derniers venus dans la couronne des vieux-quartiers, nous réinventâmes tout : les lois, les codes de l'urbain, les rapports de voisinage, les règles d'implantation et de construction. Au commencement, autour des réservoirs, ce n'étaient que campêches et ti-baume avec (derrière les campêches et ti-baume) d'autres campêches et d'autres tibaume. Ces plantes y avaient proliféré à la suite d'une rupture des équilibres qui fondent la diversité des raziés. Quand nous vinmes, nous amenâmes la campagne : charge de citronniers, balan de cocotiers, bouquets de papayers, touffes de cannes à sucre, haillons des bananiers, pieds-goyaves, piments, letchis, fruits-à-pain tant bénis, pieds-d'avocats, et un charroi d'herbesci et d'herbes-ça, aptes à soigner les maux, les douleurs de coeur, les blesses (sic) à l'âme, les floraisons songeuses de la mélancolie. (Texaco, p. 348)

\section{FREE SOIL}

We from Texaco, last to join the wreath of the old Quarters, we reinvented everything: laws, urban codes, neighborhood relations, settlement and construction rules. In the beginning, around the reservoir tanks, there were only logwood brush and wild sage, with (behind the logwood and wild sage) more logwood and wild sage. These plants had proliferated following a rupture in the original balance of the thickets. When we came, we brought the countryside with us: carts of lemon trees, swaying coconut trees, bunches of papaya trees, tufts of sugarcane, tatters of plantains, guavas, peppers, lichees, the blessed breadfruit, the avocado trees, and a mixture of this grass and that grass to cure the aches, the heart's sufferings, the soul's wounds, the dreamy flowerings of melancholy. (Texaco/Tr., : p. 317)

This passage with its enumeration of Caribbean flora and regional expressions like 'pieds-goyaves, pieds-d'avocats' for 'goyaviers' 
and 'avocatiers' or the metaphorical 'haillons des bananiers' referring to the banana leaves ravaged by the wind, would have represented a considerable challenge for a translator not familiar with the region's landscape.

It is worthwhile reiterating here points made elsewhere about Chamoiseau's handling of the interplay between French and Creole in Texaco. Chamoiseau uses various techniques of interaction at the levels of 'lexicon, syntax and speech' to create what has been described as a 'Creole-like effect.' (N'Zengou-Tayo, 1997, p. 87). This is the same effect translators achieve in English by using similar means, for example, creating a sort of 'creolized English' by employing broad features shared by anglophone Creoles: vocabulary, pronominal usages, uninflected verbs, for example, without localizing the 'Creole' to a specific community. Some of Chamoiseau's effects are impossible to achieve in translation by parallel means. In such cases the translator is forced to opt for either the Creole or the French meaning/usage, so at times the English reader is struck but perhaps not as 'disconcerted' as her/his French or Creole counterpart. This may be viewed as a gain or a loss depending on one's point of view. There are translators who feel that everything is to be gained by making an author's 'opacity' transparent to readers. One such example is the use of words like 'bay' (OF: bailler) for 'donner,' which is consistently translated into English as 'give' or the creole word 'bagage' for 'thing' as in "Bagage bizarre, l'habitation était pour lui devenue une sorte de havre" (Texaco, p. 61), which in the English version becomes "Strange baggage, the plantation had become for him a kind of haven." (Texaco /Tr., p. 48) The translator in English being forced to choose, has opted for the equivalent to the French-meaning word, which strikes us in English because of its strangeness, but does not confuse. At times however this could lead to confusion or even misreading (on the part of translator/reader) as in the case of the following passage:

She would be caught, needle in the air, listening to the harmonies of a throaty mandolin. The shrews smelled sentimental baggage. They imagined that she was in love with a chimera, an unfaithful bird, a troublemaking wind. Esternome my papa noticed it from afar and saw it up close on Sundays when they roasted game birds by the river." (Texaco, Tr., p. 49) 
for:

On la surprenait l'aiguille en l'air, attentive aux accords d'une profonde mandoline. Les maquerelles y voyaient bagage du sentiment sans pourtant lui connaître le moindre rendez-vous. On l'imagina donc amoureuse d'une chimère, d'un oiseau inconstant ou d'un vent mâle troubleur. Esternome mon papa l'apercevait de loin, de plus près le dimanche lorsqu'ils grillaient ensemble du gibier de ses chasses au bord de la rivière. (Texaco, p. 60)

A reading of 'bagage du sentiment' as 'a thing,' 'a matter,' something having to do with her feelings, i.e. a romantic liaison, (although they did not know of her ever having had any rendezvous/romantic meetings) would make it clear that this led the women to completely misunderstand the situation. The English version gives the impression that Esternome's Mama may indeed have been 'in love with a chimera' especially as the phrase 'sans pourtant lui connaitre le moindre rendez-vous' is omitted in English, (one wonders why?) whereas this is not true in the French. And that "Esternome mon papa l'apercevait de loin" could be rendered as 'Esternome, my papa noticed her from afar' or 'watched her from afar.' It is clear from the context that 'on' refers in particular to 'les maquerelles', who would be given to gossip. This could be considered as an instance of the 'interliminal.' The significance of the sentence is also altered by the omission of 'male,' the fact that they imagined she was affected by 'un vent mâle troubleur' a 'male' troublemaking wind. In this context 'troubleur' becomes stronger than 'troublemaking.'

Another of Chamoiseau's techniques, often in reporting direct speech utterances, is to juxtapose Martinican Creole phrases/sentences and their French versions, instead of giving the translations/explanations in a footnote creating an "echoing sound effect" (N'Zengou-Tayo, 1997, p. 87). Here the translators have noted that:

In the original, the author's translation usually follows any Creole sentence: wherever the author's translation diverges substantially from the meaning of the Creole, we have included our own footnoted version. We distinguish our footnotes from the author's by the use of brackets. ("Translators' Note") 
The translator achieves this 'echoing' effect in English by repeating the creole phrase as in the original (French) version of the novel and then giving the translation as Chamoiseau does, in standard English: "Alors elle m'abaissa la tête et me dit : Pre die ba Papa'w ich mwen, Prie pour ton papa mon fils..." (Texaco, p. 48) rendered as: "So she put my head down and said: Predie ba papa'w ich mwen, Pray for your papa, my son..." (Texaco/Tr., p. 48). This choice would seem to be the most appropriate especially as it avoids the dilemma of having to choose a particular anglophone Creole (local to only one territory) at the risk of having to justify this choice. But it is also perfectly representative of communities, particularly rural and older communities, in parts of the Anglophone Caribbean like Dominica, St Lucia, and even parts of Grenada or Trinidad, where a French-based Creole, very similar to Martinican Creole, exists alongside standard English.

However the two versions of the novel do not always run parallel in their use of French and Creole, no doubt reflecting a difference in readership demands as in:

But (saki pa bon pou zwa pa pe bon pou kanna, food not fit for geese is not fit for ducks) at least they had begun to understand that freedom was indivisible, that theirs was tied to that of the land slaves and all the other wretches. (Texaco/Tr., p. 93)

for:

Mais, (saki pa bon pou zwa pa pe bon pou kanna) ils avaient quand même commencé à comprendre que la liberté n'étant pas divisible, la leur allait en grappes avec celle des nèg-terre et l'engeance pleine des malheurs." (Texaco, p. 108)

Note that here there is no French 'echo' and no italics in the Creole original - Martinican readers would perhaps be familiar with the proverb. (For a fuller discussion of this question see N'ZengouTayo, 1997, p. 87)

\section{Challenges: some comments}

Discussing post-colonial writing Ashcroft et al. (1989) refer to what they call 'appropriation,' defined as 'the process by which language is taken and made to 'bear the burden' of one's own 
cultural experiences." (p. 38). Thus references to historical and cultural events and phenomena which occur frequently in West Indian/Caribbean texts are particularly challenging for translators, especially as they could easily be missed. One thinks of significant expressions such as the 'Middle Passage' always written in capitals, which resonates in Caribbean English, whereas a literal rendering would have no such significance for a francophone Caribbean reader. In these cases care must be taken to find references in francophone texts, which translate the reality, here "la traversée atlantique,' in the context of the slave trade. The same is true of seemingly casual references to myths, legends, superstitions, customs, which belie a deeper underlying meaning or belief system, or references to persons which habitually use skincolor or physical characteristics, for example 'chabine,' 'câpresse,' 'chapée-coulie,' in the French West Indies for women, or 'nègre' meaning simply 'man' in Haiti. For example, 'un nègre rouge' refers to a red-haired person of African descent or a 'brown man' in Caribbean English. Thus, speaking of his 'Grand-manman Blanchisseuse' the narrator says:

C'était une négresse rouge. Elle avait échappé aux horreurs de la canne en travaillant à la Grand-case. (Texaco, p. 49)

Translated this becomes:

She was a red blackwoman. She had escaped the sugarcane horrors by working in the Big Hutch. (Texaco/Tr., p. 38).

'A red blackwoman' in English strikes one as odd, whereas in French Caribbean usage 'une négresse rouge' is a familiar descriptive term for women of a certain hue/complexion. Mayotte Capecia's novel La négresse blanche, set in Martinique in the 40s plays on this familiar usage of négresse rouge. A number of English equivalents exist in the Caribbean: in Jamaican English for example, such a person would be described as 'red' or a 'red woman' and everyone would understand that racially this refers to a 'blackwoman'. The terms 'reddibo / red Ibo' or 'red naygah'(this last usually pejorative), also exist, so in view of the historical context (old usage: 'negress' or 'negro woman'), 'red negress' is also a possible acceptable alternative. We also note with the translators that "Chamoiseau uses the French word nègre (negro) in the Creole sense of 'man'." (Texaco /Tr., p. 14). The sentence 
could therefore read: "She was a red woman. She had escaped the horrors of the cane by working in the Big House/Massa's House/the Great House." 'Case' in the French Caribbean is an everyday word, meaning 'house', 'dwelling.' 'La Grand-case' on the plantation is the master's or owner's dwelling, referred to in the English speaking Caribbean as the 'Great House' (standard, formal or official writing) or conceivably as the 'Big House' in everyday language by those who do not live there. 'Hutch' in this context would never be encountered in the Caribbean, or in Standard English. 'Massa's House' might be a particularly resonant choice in view of the phrase "Conquête de la Grand-case" translated as "The Conquest of the Big Hutch" (Tr., p. 43), which serves as the title for the section beginning on page 53 .

The transposition of 'de la canne' into the adjectival 'sugarcane' also operates as a means of attenuating the 'horrors of the plantation' which would be conveyed by keeping the original structure 'the horrors of the cane(s).'

We found some expressions that could be adjusted to increase effect. For example, 'nèg-en-terre' (p. 108) was translated 'land slaves' (p. 93) instead of the commonly used 'field slaves.' "She felt her belly plunge into a wet season" (p. 41), in Caribbean English 'rainy season,' was used for the very Caribbean "son ventre pris d'hivernage" meaning (similar to the French expression "faire hiver dans les poches") that she was starving. Inappropriate choices in lexicon (minor in Réjouis and Vinokurov but more significant in other translated texts) could be avoided relatively easily. They could be replaced by regional expressions which would enhance the work in its translated versions if publishing houses systematically used Caribbean native speakers (of Creole(s), Dutch, English, French, Spanish, etc., depending on the target language) as readers for Caribbean texts. Interestingly, knowledge of the various Caribbean languages may also occasionally lead to 'overtranslation' as is the case of 'tilapia,' in English also 'tilapia,' a kind of fresh water fish, rendered in English as "the small lapia fish" (Texaco/Tr., p. 41) from the Creole 'ti' (petit, small).

A translation "records how the translator understood" a text (Gaddis-Rose). While having a Caribbean translator for a 
Caribbean text does not guarantee a good or better translation, having a good Caribbean translator is certainly a plus, as evidenced for example by Michael Dash's translations of Glissant's $L a$ lézarde and more recently Gisèle Pineau's La grande drive des esprits. This is especially true in a novel like Texaco where it is a distinct advantage that the translator is creolophone in addition to being francophone.

\section{Conclusion}

Agnes Scott Langeland reminds us that:

The task of translating is a pursuit full of traps and hidden dangers and barrowloads of open dilemmas. (1998, p. 24)

There is no such thing as a perfect translation and there is no guarantee that a Caribbean translator will avoid all the pitfalls in translating a Caribbean text. The two translations we have studied in this article show the importance of background research particularly in the case of the Caribbean, where cultures are still dominated or minority cultures. Most translators of Caribbean fiction stumble over cultural elements and natural environment. The question of language register and the relationship between colonial languages and Creoles is also a problem though the translator can always keep the Creole in the text with a juxtaposed translation. Translations into Caribbean English highlight the problem of choosing among dialectal variations (Jamaican / Trinidadian / Barbadian / Eastern Caribbean English) or creating a fictional 'standard' Caribbean English. In the case of the emerging English and Spanish writers of Haitian origin, translating their works into French requires familiarity with the body of Haitian literature in French in order to be able to maintain cultural references present in their works. At a time when globalization, the Internet, and the New World order are shaping world culture, the development of Caribbean translation becomes crucial in order to guard against stereotyping and promote cross-cultural exchange. While we remember that literary translation has played and still plays a key role for the development of World Literature, we would like to advocate a de-centered approach to the translation of works from the Caribbean. We would like to see a policy on the part of publishing houses, which would consult readers from the Caribbean before publishing translations of works from the region. 


\section{University of West Indies}

\section{References}

\section{Texts}

CHAMOISEAU, Patrick (1992). Texaco. Paris, Gallimard.

- (1998). Texaco. Translated in American-English by RoseMyriam Réjouis and Val Vinokurov. New York, Vintage International -Vintage Books.

DANTICAT, Edwidge (1994). Breath, Eyes, Memory. New York, Soho Press.

- (1995). Le cri de l'oiseau rouge. Translated into French by Nicole Tisserand. Paris, Pygmalion/Gérard Watelet. Paris, Pocket, 1997.

\section{References}

ASHCROFT, Bill, Gareth GRIFFITHS and Helen TIFFIN (eds) (1989). The Empire Writes Back: Theory and Practice in PostColonial Literature. London, Routledge, 1989.

BRATHWAITE, Edward Kamau (1976). "Caribbean Man in Space and Time." Carifesta Forum. An Anthology of 20 Caribbean Voices. Edited by John Hearne. Kingston, Institute of Jamaica \& The Jamaica Journal. (reprint from Savacou).

BENÍTEZ-ROJO, Antonio (1992). The Repeating Island. The Caribbean and the Postmodern Perspective. Tr. James E. Maraniss. Durham, Duke University Press.

BERMAN, Antoine (1984). L'épreuve de l'étranger. Paris, Gallimard.

BERNABÉ, Jean, Patrick CHAMOISEAU et Raphaël CONFIANT (1989). Éloge de la créolité. Paris, Gallimard. English translation by Mohammed Taleb-Kyar (1990). Gallimard, bilingual edition, 1995. 
CLITANDRE, Pierre (1982). Cathédrale du mois d'août. Paris, Syros. English Translation by Bridget Jones. (1987). Cathedral of the August Heat. London, Readers International, Inc.

CONDÉ, Maryse (1986). Moi, Tituba sorcière... noire de Salem. Paris, Mercure de France. English Translation by Richard Philcox. (1992) I Tituba Black Witch of Salem. Charlottesville, University of Virginia Press.

- (1987). La vie scélérate. Paris, Seghers. English Translation by Victoria Reiner (1992). Tree of Life. New York, Ballantine Books.

- (1989). Traversée de la mangrove. Paris, Mercure de France. English Translation by Richard Philcox. (1995) Crossing the Mangrove. New York, Anchor Books/Doubleday.

CORDONNIER, Jean-Louis (1995). Traduction et culture. Paris, Hatier/Didier - Crédif - Langues et apprentissage des langues.

GADDIS ROSE, Marilyn (1997). Translation as Literary Criticism, Translation as Analysis. Manchester, UK, St. Jerome Publishing - Series: Translation Theories Explained.

GLISSANT, Édouard (1990). Poétique de la relation. Paris, Gallimard.

KADISH, Doris (1996). "Esclavage et Féminité: Maryse Condé et ses traducteurs." In L'Oeuvre de Maryse Condé. À propos d'une écrivaine politiquement incorrecte. Paris / Montréal, L'Harmattan. pp. 231-247.

KUNDERA, Milan (1991). "Beau comme une rencontre mythique”. L'Infini, n⿳0 34, Été, pp. 50-62.

Karibel Magazine, $\mathrm{n}^{0}$ 3, Nov.-Dec. 92, Karaib Perspectives. Martinique, p.1.

MASSARDIER-KENNEY, Françoise (1996). "La question de la traduction plurielle ou "les traducteurs de Maryse Condé"'. In L'Euvre de Maryse Condé. À propos d'une écrivaine politiquement incorrecte. Paris/Montréal, L'Harmattan, pp. 249- 
258.

N'ZENGOU-TAYO, Marie-José (1996). "Littérature et diglossie: créer une langue métisse ou la " chamoisification 》 du français dans Texaco de Patrick Chamoiseau." TTR Le Festin de Babel / Babel's Feast. Vol. IX, 1, pp. 155-176. English version (1997). "Literature and Diglossia: The Poetics of French and Creole 'Interlect' in Patrick Chamoiseau's Texaco. Caribbean Quarterly, Vol. 43, $\mathrm{n}^{\circ} 4$ (December). Kingston, Jamaica, pp. 81-101.

PHILCOX, Richard (1996). "Traduire Traversée de la Mangrove." In L'Euvre de Maryse Condé. À propos d'une écrivaine politiquement incorrecte. Paris / Montréal, L'Harmattan, pp. 221230.

RÉJOUIS, Rose-Myriam (1998). "Afterword." Texaco. New York, St. Jerome Press - Vintage International.

SCOTT LANGELAND, Agnes (1998). "Crossing (S)words: Tranlating Dag Solstad's Professor Andersen's Night." In Other Words: The Journal for Literary Translators, Summer, $\mathrm{n}^{\circ} 11, \mathrm{pp}$. 24-34.

SHEA, Renée H. and Edwidge Danticat (1996). "The Dangerous Job of Edwidge Danticat: An Interview." Callaloo, vol. 19, $\mathrm{n}^{\circ} 2$, (Spring). Baltimore/ Charlottesville, The Johns Hopkins University Press/ University of Virginia, pp, 382-389.

ABSTRACT: Translators on a Tight Rope: The Challenges of Translating Edwidge Danticat's Breath, Eyes, Memory and Patrick Chamoiseau's Texaco - For Caribbean intellectuals and scholars, translation of Caribbean literary texts has a key role to play for breaching the language barriers in the Caribbean and fostering regional integration. However, most publishing houses are located in the industrialized North, i.e. in countries which had colonial interests in the region. The targeted market of these publishers is located in a region which tends to exoticize the Caribbean. Henceforth, translating Caribbean literature can be like walking on a tight rope, since the translator would have to negotiate carefully between exoticism and faithfulness to the Caribbean culture. In addition, at least for the Dutch, French and 
English-speaking Caribbean, there is also the issue of bilingualism: use of French in relation with use of Haitian / Martinican / Guadeloupian Creole, use of English with Jamaican / Trinidadian Creole or a French-based Creole (Dominica, Grenada, and St Lucia). Against this background, we examined two translations, one from English into French (Edwidge Danticat's Breath, Eyes, Memory, 1994), the other from French into English (Patrick Chamoiseau's Texaco, 1992). We analyzed the translators' strategies in order to convey the Haitian and Martinican cultures. We also discussed their rendering of the bilingual shifts present in both texts. One translator was more successful than the other, which also raised the issue of 'scholar' translation versus 'non scholar' translation. In conclusion, Caribbean academics have to be watchful of the translations of literary works of the region since these translations, which do not aim primarily at the regional audience will nevertheless impact on cultural relationships in the region.

RÉSUMÉ : Traduire Breath, Eyes, Memory d'Edwidge Danticat et Texaco de Patrick Chamoiseau : un défi pour les traducteurs - Pour les intellectuels et les universitaires de la région des Antilles, la traduction des textes littéraires régionaux a un rôle capital à jouer pour permettre de dépasser les barrières linguistiques et contribuer à l'intégration régionale. Or, la plupart des maisons d'édition sont implantées dans les pays industrialisés du nord c'est-à-dire dans des pays ayant eu des intérêts coloniaux dans la région. De plus, le public cible de ces maisons d'édition vit dans une région qui a toujours eu tendance à rechercher l'exotisme des Antilles. Il s'ensuit que la traduction des ouvres littéraires caribéennes peut se révéler un exercice périlleux puisque le traducteur devra sans cesse négocier entre la tentation de l'exotisme et le respect de la culture caribéenne. Par ailleurs, et du moins pour les pays anglophones, francophones et néerlandophones des Antilles, la question du bilinguisme se pose également : utilisation du français et du créole guadeloupéen / haïtien / martiniquais, de l'anglais et du créole jamaïquain / trinidadien ou encore des créoles à base française dans le cas de la Dominique, de la Grenade et de Sainte-Lucie. C'est donc dans ce contexte que nous avons analysé deux traductions, l'une allant de l'anglais vers le français (Breath, Eyes, Memory d'Edwidge Danticat, 1994) et l'autre du français vers l'anglais (Texaco de 
Patrick Chamoiseau, 1992). Nous avons étudié la manière dont les traductrices arrivaient à faire passer les cultures haïtienne et martiniquaise. Nous avons également discuté leur traitement des instances de bilinguisme, présentes dans les deux textes. Une traductrice y est mieux parvenue que l'autre, ce qui nous a conduites à soulever le problème de la traduction " universitaire » par rapport à la traduction « non-universitaire ». Nous en concluons que les universitaires caribéens se doivent de prêter une attention particulière aux traductions des cuvres littéraires de la région puisque ces dernières, bien que ne visant pas en premier lieu le public régional, auront néanmoins un impact sur les relations interculturelles dans la région.

Key Words: Translation, Exoticism, Otherness, Creole, Caribbean Literature.

Mots-clés : Traduction, exotisme, altérité, Créole, littérature caribéenne.

Marie-José N'Zengou-Tayo : Department of Modern Languages and Literatures, University of the West Indies, Mona Campus, Mona, Kingston 7, Jamaica, W.I.

Courriel: mnzeng@uwimona.edu.jm,mnzeng@cwjamaica.com

Elizabeth (Betty) Wilson : Department of Modern Languages and Literatures, University of the West Indies, Mona Campus, Mona, Kingston 7, Jamaica, W.I.

Courriel: eawilson@uwimona.edu.jm 